\title{
Active packaged lamb with oxygen scavenger/carbon dioxide emitter sachet: physical-chemical and microbiological stability during refrigerated storage
}

Cordeiro em embalagem ativa com sachê absorvedor de oxigênio/emissor de gás carbônico: estabilidade físico-química e microbiológica durante armazenamento refrigerado

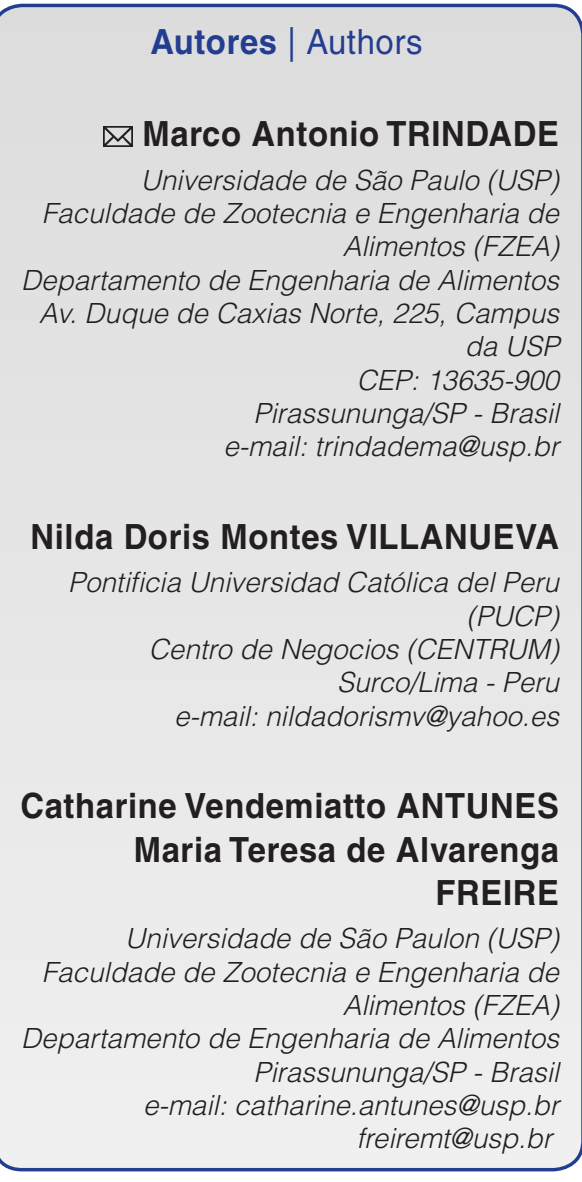

Autor Correspondente / Corresponding Author

Recebido / Received: 29/10/2012 Aprovado / Approved: 10/09/2013 Publicado / Published: set./2013

\section{Summary}

Lamb meat has been commercialized in Brazil almost exclusively as a frozen product due to the longer shelf life provided by freezing when compared to refrigeration. However, as a result of the current trend of increased demand for convenience products, a need has emerged for further studies to facilitate the marketing of refrigerated lamb cuts. The aim of the present study was to evaluate the contribution of active packaging technology in extending the shelf life of lamb loins (Longissimus lumborum) stored under refrigeration $\left(1 \pm 1^{\circ} \mathrm{C}\right)$ when compared to the traditional vacuum packaging. For this purpose, two kinds of sachets were employed: oxygen scavenger sachet and oxygen scavenger/carbon dioxide emitter sachet. Experiments were conducted in three treatments: 1) Vacuum (Control), 2) Vacuum + oxygen scavenger sachet and 3) Vacuum + oxygen scavenger/carbon dioxide emitter sachet. Microbiological (counts of anaerobic psychrotrophs, coliform at $45^{\circ} \mathrm{C}$, coagulase-positive staphylococci, Salmonella and lactic acid bacteria) and physical-chemical (thiobarbituric acid reactive substances, objective color, $\mathrm{pH}$ value, water loss from cooking and shear force) analyses were carried out weekly for a total storage period of 28 days. The experiment was performed three times for all treatments. Results showed that the lamb meat remained stable with respect to the majority of the evaluated physical and chemical indexes and remained within the standards established by Brazilian legislation for pathogenic microorganisms throughout the storage period in all three packaging systems. However, all treatments presented elevated counts of anaerobic psychrotrophic microorganisms and lactic acid bacteria, reaching values above $10^{7} \mathrm{CFU} / \mathrm{g}$ at 28 days of storage. Thus, under the conditions tested, neither the oxygen scavenger sachet nor the dual function sachet (oxygen scavenger/ carbon dioxide emitter) were able to extend the shelf life of refrigerated lamb loin when added to this meat vacuum packaged.

Key words: Lamb; Vacuum packaging; Active packages; Microbiology; Oxidation. 


\section{Resumo}

A carne de cordeiro é comercializada no Brasil quase que exclusivamente na forma congelada, em função da maior vida útil fornecida pelo armazenamento congelado quando comparada à vida útil do armazenamento refrigerado. No entanto, devido à tendência de aumento da demanda por produtos de conveniência, surge a necessidade de mais estudos para permitir a comercialização da carne ovina na forma refrigerada. O objetivo deste estudo foi avaliar a contribuição da tecnologia de embalagens ativas na extensão da vida útil de lombos de cordeiro (Longissimus lumborum) armazenados sob refrigeração $\left(1 \pm 1^{\circ} \mathrm{C}\right)$, em comparação com a embalagem tradicional a vácuo. Para tanto, dois tipos de sachês foram empregados: sachê absorvedor de oxigênio e sachê absorvedor de oxigênio/ emissor de gás carbônico. Foram avaliados três tratamentos: 1) Vácuo (controle), 2) Vácuo + sachê absorvedor de oxigênio e 3) Vácuo + sachê absorvedor de oxigênio/emissor de gás carbônico. Durante 28 dias, foram realizadas semanalmente análises microbiológicas (contagens de psicrotróficos anaeróbios, coliformes a $45^{\circ} \mathrm{C}$, estafilococos coagulase positiva, Salmonella e bactérias láticas) e físico-químicas (substâncias reativas ao ácido tiobarbitúrico, cor objetiva, valor de $\mathrm{pH}$, perdas no cozimento e força de cisalhamento). Os experimentos foram repetidos três vezes para todos os tratamentos. Os resultados demonstraram que a carne de cordeiro embalada nos três diferentes sistemas manteve-se estável, durante todo o período de armazenamento, em relação à maioria dos parâmetros físicos e químicos avaliados, e dentro dos padrões estabelecidos pela legislação brasileira para microrganismos patogênicos. No entanto, todos os tratamentos apresentaram contagens elevadas de microrganismos psicrotróficos anaeróbios e bactérias láticas, atingindo valores superiores a $10^{7} \mathrm{UFC} / \mathrm{g}$, aos 28 dias de armazenamento. Assim, nas condições testadas, nenhum dos dois tipos de sachês avaliados (sachê absorvedor de oxigênio e sachê absorvedor de oxigênio/emissor de gás carbônico) foi capaz de estender a vida útil do lombo de cordeiro, quando incorporados a essa carne embalada a vácuo.

Palavras-chave: Cordeiro; Embalagem a vácuo; Embalagens ativas; Microbiologia; Oxidação. 
TRINDADE, M. A. et al.

\section{Introduction}

The sheep production is increasing in Brazil due to growing demand for this product. Thus, there is a consequent need for higher product quality (LANDIM et al., 2011). The meat quality parameters involve several features and are related to the consumer's expectations (COSTA, 2011). Some attributes such as $\mathrm{pH}$, color and chemical characteristics are very important and affect consumer's preferences (KAMRUZZAMAN et al., 2012; MADRUGA, et al., 2006). Methods for meat preservation are core factors to quality maintenance. The conservation aims at preserving the nutritional and sensory characteristics, besides avoiding the action of microorganisms and their toxins, extending the product shelf life (ANVISA, 2004).

Packaging technologies take an important role in preserving perishable food, preventing contamination, delaying spoilage, permitting some enzymatic activity to improve tenderness, reducing weight loss, and where applicable, ensuring the red color due to the pigment oxymyoglobin (SINGH et al., 2011; JEREMIAH, 2001). Different systems have been used for fresh meat, ranging from overwrap packaging for short-term chilled storage and/or retail display, to a diversity of specified modified atmosphere systems for longer-term chilled storage and/ or display, to vacuum packaging, bulk-gas flushing or using $100 \%$ carbon dioxide for long-term chilled storage (KERRY et al., 2006).

Commercially, the color stability is one of the most important quality parameters considered by consumers and it is related to the content of myoglobin in muscle and the distribution of myoglobin derivatives on the meat surface. According to Channon et al. (2005) the myoglobin content affects muscle lightness and redness, while deoxymyoglobin, oxymyoglobin and metmyoglobin can influence lightness, redness and yellowness of lamb.

Chen et al. (2012) consider that vacuum-packaging is applied for primary cuts, while modified atmosphere packaging is more suitable for retail displays of meat. The vacuum packing is considered to be the simplest form of modified atmosphere, being often used for packaging of refrigerated meat cuts, which are highly susceptible to biological degradation, consisting of a system which contributes to a longer lifetime due to reduction of aerobic microorganism development, oxidation and discoloration (JAY et al., 2005; FELLOWS, 2006; RICCIARDI, 2008).

The reduction of residual $\mathrm{O}_{2}$ of hermetically sealed packages results in lower rates of metabolism and growth of aerobic microorganisms. Most spoilage microorganisms require $\mathrm{O}_{2}$ to grow and cause off-odors in the presence of sufficient oxygen. In addition, reactions involving $\mathrm{O}_{2}$ can result in oxidative breakdown of foods such as fats, proteins and vitamins (BRODY et al., 2001; JEREMIAH,
2001). Carbon dioxide $\left(\mathrm{CO}_{2}\right)$, a gas with fungistatic and bacteriostatic characteristics, reduces or inhibits microbial growth, and consequently extends the useful lifetime of the packaged product (ARVANITOYANNIS and STRATAKOS, 2012; SINGH et al., 2011).

The inhibitory and stimulatory effects of $\mathrm{CO}_{2}$ are dependent on partial pressure, concentration, and temperature of $\mathrm{CO}_{2}$, volume of headspace gas, acidity, water activity, and the type of microorganisms, type of product, the microbial growth phase, and the growth of the medium used for maximum antimicrobial effect. The storage temperature of modified atmosphere packaged products should be kept as low as possible because the solubility of $\mathrm{CO}_{2}$ decreases dramatically with increasing temperature. Dissolved $\mathrm{CO}_{2}$ could increase the lag phase and generation time of microorganisms (SINGH et al., 2011). Its effect on the microbial inhibition is also related to the formation of carbonic acid causing $\mathrm{pH}$ reduction (FELLOWS, 2006; JEREMIAH, 2001; GENIGEORGIS, 1985). On the other hand, the presence of high levels of $\mathrm{CO}_{2}$ can cause meat discoloration due to formation of metmyoglobin (ARVANITOYANNIS and STRATAKOS, 2012; SINGH et al., 2011; JEREMIAH, 2001). In recent years active packaging and intelligent packaging have been studied with meat products. The active packages are defined as a system that involves interactions between package or packaging components and food or the gas composition inside the package. However, few studies have been conducted with adding sachet agents to the packaging systems. The $\mathrm{O}_{2}$ absorber sachet is a sterile product consisting of aging retardants, with the main purpose of increasing the shelf life of products by gradual removal of $\mathrm{O}_{2}$ inside packages. Oxygen absorbers are able to inhibit the growth of aerobic bacteria, moulds and stop alterations of pigments and flavours. The most common absorber consists of a small size oxygen permeable sachet containing an iron-based powder along with a catalyst (CRUZ et al., 2008; BRODY et al., 2001; AZEREDO et al., 2000). $\mathrm{O}_{2}$ permeates through plastic polymers according to their oxygen transmission rates, but it generally permeates more slowly than carbon dioxide. It is very soluble in water, especially in cold water and is readily absorbed by high moisture. The presence of $\mathrm{O}_{2}$ promotes the oxidation of unsaturated fatty acids in lipids, which lead to rancidity and eventual spoilage, while lowering the $\mathrm{O}_{2}$ level in modified atmosphere packaging reduces metabolic and chemical oxidation rates but the outgrowth of anaerobic pathogens might be stimulated (ARVANITOYANNIS and STRATAKOS, 2012).

In order to evaluate effectiveness of active packaging, Cruz et al. (2007) exposed oxygen-absorbing sachets to different conditions or relative humidity and temperature, demonstrating that oxygen absorption was higher as relative humidity was increased. The authors 
Active packaged lamb with oxygen scavenger/carbon dioxide emitter sachet: physical-chemical and microbiological stability during refrigerated storage

TRINDADE, M. A. et al.

reported that oxygen-absorbing sachets were most active under $25{ }^{\circ} \mathrm{C}$ and $85 \%$ relative humidity.

$\mathrm{CO}_{2}$ generators have also been applied in the food industry, due to their activity against aerobic bacteria as well as fungi. It has been stated that increased concentrations (10-80\%) are desirable due to better effectiveness in reducing the surface microbial growth. Considering the meat chain, generation of $\mathrm{CO}_{2}$ can be reached by using a perforated tray in which a porous sachet containing sodium bicarbonate or ascorbate is placed. When the meat exudate contacts it, $\mathrm{CO}_{2}$ is produced (ARVANITOYANNIS and STRATAKOS, 2012; BRODY et al., 2001).

The incorporation of carbon dioxide $\left(\mathrm{CO}_{2}\right)$ emitter sachets into vacuum package could bring the advantage of $\mathrm{CO}_{2}$ gas without the need of special equipment for gas injection. This would be useful for small slaughterhouses, which is the case of ovine chain in Brazil. Given the above and the lack of specific information about the use of active packaging in the consulted scientific literature for lamb meat, the objective of this study was to evaluate if the incorporation of two types of sachets (one oxygen absorber sachet and a dual function sachet - oxygen absorber and carbon dioxide emitter) in vacuum packages could extend shelf life of lamb meat stored under refrigeration.

\section{Material and methods}

\subsection{Raw materials and modified atmosphere packaging}

Samples were obtained from the loins of 90 intact male lambs from crosses of Santa Inês X Dorper. The lambs were aged between five and six months with a live weight between 35 and $40 \mathrm{~kg}$. The animals were slaughtered in a commercial slaughterhouse according to the standards for animal welfare and good manufacturing practices established by Brazil's Ministry of Agriculture, Livestock and Food Supply. The carcasses were refrigerated $\left(4^{\circ} \mathrm{C}\right)$ for 24 hours, suspended by the Achilles tendon. The samples were then obtained from cuts between the first and sixth lumbar vertebrae (Longissimus lumborum) on both sides of the carcasses.

All of the samples were packed in perforated Drylock expanded polystyrene trays $(140 \times 178 \times 25 \mathrm{~mm})$ containing absorbent for liquid drainage (21P LinStar, LINPAC). The trays were individually placed in $180 \times$ $370 \mathrm{~mm} 7$ layer EVA/PVDC plastic bags; $56.5 \pm 0.2 \mu \mathrm{m}$ thickness; nominal $\mathrm{O}_{2}$ permeability of $25 \mathrm{~cm}^{3} \cdot \mathrm{m}^{-2}$. day ${ }^{-1}$ (1 atm $/ 23{ }^{\circ} \mathrm{C} / 0 \% \mathrm{RH}$ ) and water vapor permeability of $10 \mathrm{gH}_{2} \mathrm{O} \cdot \mathrm{m}^{-2}$.day ${ }^{-1}\left(1 \mathrm{~atm} / 38{ }^{\circ} \mathrm{C} / 90 \% \mathrm{RH}\right)(\mathrm{BB} 2800$, CRYOVAC). Before sealing, sachets (two units per bag) were placed inside the plastic bags but outside the trays, thus avoiding meat contact. Three treatments were performed: 1) Vacuum packaging; 2) Vacuum packaging plus oxygen scavenger sachet (model 504BZ-50CC, brand Didai) and 3) Vacuum packaging plus double function sachets (oxygen scavenger/carbon dioxide emitter, model 504E-50CC, brand Didai). The packaged samples from all treatments were kept refrigerated $\left(1 \pm 1^{\circ} \mathrm{C}\right)$ for 28 days in a B.O.D. (Model MA 415, Brand Marconi).

\subsection{Evaluation of the lamb loins}

A completely randomized $3 \times 5$ factorial design (three treatments and five storage times) was used to analyze the microbiological, physical and chemical parameters. The three treatments were assessed with respect to these parameters at five storage times $(0,7$, 14,21 and 28 days). Three replicates were performed for each treatment at each storage time.

The physicochemical and microbiological measures of the experimental treatments were analyzed using a Factorial ANOVA $(p \leq 0.05)$, including the effects of treatment, storage time and treatment $\times$ storage time in the statistical model. In order to evaluate the differences in physicochemical and microbiological characteristics among the treatments, paired comparisons of the means were carried out using the Tukey HSD test $(p \leq 0.05)$. The statistical data analysis was performed using STATISTICA 6.0 for Windows software (Statsoft Inc., Tulsa, Okla., U.S.A.).

\subsection{Microbiological analysis}

The total counts of aerobic and anaerobic psychrotrophic microorganisms were performed according to the methodology described by Johnston and Tompkin (1992). The presence of Salmonella was determined using a rapid pre-enrichment method (A.O.A.C. 2003.09). Coagulase-positive staphylococci were identified using the A.O.A.C. 2003.11 method. Thermotolerant coliforms at $45^{\circ} \mathrm{C}$ were identified using the A.O.A.C. 998.08 method (HORWITZ and LATIMER, 2005), and lactic acid bacteria were identified using the method described by Hall et al. (2001).

\subsection{Physical and chemical analysis}

To analyze the chemical composition of the samples, the official methodology AOAC (HORWITZ and LATIMER, 2005) was used to measure moisture (950.46), fixed mineral residue (or ash) (920.153) and protein (981.10). The lipid content was determined using the method described by Bligh and Dyer (1959).

A portable colorimeter (HunterLab, MiniScan XE) was used for the objective color analyses using the $L^{*}$, $a^{*}$ and $b^{*}$ scales of the CIELab evaluation system. A $D_{65}$ illuminant was used at an observation angle of $10^{\circ}$ and with a cell opening of $30 \mathrm{~mm}$. The readings were obtained 
Active packaged lamb with oxygen scavenger/carbon dioxide emitter sachet: physical-chemical and microbiological stability during refrigerated storage

TRINDADE, M. A. et al.

at three different points 30 minutes after the exposure of the sample's surface to the atmosphere.

The $\mathrm{pH}$ values were measured using a $\mathrm{pH}$ meter (HANNA, HI 99163) with a combined electrode for performing readings in triplicate with perforation of the meat.

The same samples used for $\mathrm{pH}$ and color analyses were subjected to an evaluation of the extent of lipid oxidation using the thiobarbituric acid reactive substances (TBARS) assay according to Vyncke's (1970) methodology. The results of the assay were expressed as milligrams of malonaldehyde per kilogram of sample.

The water loss from cooking (WLC) was assessed according to the methodology described by Koohmaraie (1996). Samples were cooked in an electric oven at $180^{\circ} \mathrm{C}$ until the internal (geometric center) temperature reached $72{ }^{\circ} \mathrm{C}$. The WLC was determined using the following equation: WLC $=[($ Initial weight - final weight $) /$ initial weight)] $\times 100$. The results were expressed in percentage. After cooking, samples were cut individually and parallel to the muscle fibers into ten rhomboids measuring $2 \times 1$ $\times 1 \mathrm{~cm}$. The shear forces of these cuts in kilograms were determined using a Warner Bratzler texturometer.

The gas composition inside the package (headspace gas composition) was determined in each evaluation interval, using a portable gas analyzer (Dansensor, CheckPoint $\mathrm{O}_{2} / \mathrm{CO}_{2}$ ). An electrochemical sensor was used to measure $\mathrm{O}_{2}$ levels, and an infrared sensor was used to measure $\mathrm{CO}_{2}$ levels by means of puncture of packaging.

\section{Results and discussion}

\subsection{Determination of the proximate composition}

The results obtained for the proximate composition of lamb meat in the three replications are shown in Table 1. It was verified that the composition of moisture, ash, lipids and proteins from lamb loin meat (Longissimus dorsi) evaluated was consistent with data found in the literature for sheep meat (CARVALHO and BROCHIER, 2008; PINHEIRO et al., 2009). It is even evident that, despite the inherent differences among animals from the same breed, there was little variation in the proximate composition of lamb meat.

Table 1. Average proximate composition of samples of lamb loin meat (Longissimus dorsi)

\begin{tabular}{cccc}
\hline Moisture (\%) & Ash (\%) & Lipids (\%) & Proteins (\%) \\
Mean \pm SD & Mean \pm SD & Mean \pm SD & Mean \pm SD \\
$75.7 \pm 0.2$ & $1.06 \pm 0.04$ & $1.90 \pm 0.08$ & $19.5 \pm 0.5$ \\
\hline SD
\end{tabular}

$\mathrm{SD}=$ standard deviation

\subsection{Analysis of headspace gas composition}

Results of packages headspace are shown in Figure 1. Regarding oxygen concentration, it could be seen a faster decrease inside packages with sachets when compared with vacuum packaging. By the time of the first measurements, lamb packages under vacuum presented $15 \%$ of $\mathrm{O}_{2}$ while packages containing sachets showed $\mathrm{O}_{2}$ concentration below $10 \%$, probably due to the oxygen scavenging activity. This behavior continued during the storage period, when active packaging with oxygen scavenger sachets (Figure $1 \mathrm{~b}$ ) reached zero oxygen concentration on the seventh day of storage, while vacuum packages reached this concentration only after 28 days of storage.

Regarding carbon dioxide concentration, the active packaging with dual function sachets $\left(\mathrm{O}_{2}\right.$ scavenger / $\mathrm{CO}_{2}$ emitter) showed greater $\mathrm{CO}_{2}$ concentration in the headspace than packages with $\mathrm{O}_{2}$ scavenger sachets, which was desired because of the former $\mathrm{CO}_{2}$ generation capacity. However, lamb packaged under vacuum also showed a higher $\mathrm{CO}_{2}$ concentration. This could be due to $\mathrm{CO}_{2}$ emission by microorganisms because, besides not being statistically different ( $p>0.05$ ), vacuum packaged samples presented anaerobic psychrotrophic microorganisms counts almost 1 log cycle higher than samples packaged with $\mathrm{O}_{2}$ scavenger $/ \mathrm{CO}_{2}$ emitter sachets, as shown in Figure 2.

\subsection{Microbiological stability during refrigerated storage}

During the time period assessed the presence of Salmonella was not detected in any of the treatments. The counts of coagulase-positive staphylococci microorganisms were lower than $10^{2} \mathrm{UFC} / \mathrm{g}$ sample in all treatments throughout the storage period. For thermotolerant coliforms (at $45^{\circ} \mathrm{C}$ ), the counts for the three treatments during storage are shown in Figure 3. There were no differences $(p>0,05)$ among treatments and the counts decreased ( $p \leq 0.05)$ along storage period, showing maximum counts up to about $10^{1} \mathrm{UFC} / \mathrm{g}$ sample. Thus, vacuum-packed lamb loin meat and wrapped with or without the incorporation of two types of sachets, stored at $1{ }^{\circ} \mathrm{C}$ for 28 days, remained within acceptable limits established by the Brazilian legislation through RDC Resolution No. 12 (ANVISA, 2001). This standard establishes that counts scheduled for vacuum-packed meat, not aged, are $10^{4} \mathrm{CFU} / \mathrm{g}$ sample for thermotolerant coliform, $3 \times 10^{3} \mathrm{CFU} / \mathrm{g}$ sample for coagulase positive staphylococci and absence of Salmonella in $25 \mathrm{~g}$ of sample. These results are similar to those found by Fernandes et al. (2012) who did not detect Salmonella and coagulase-positive staphylococci microorganisms and obtained sporadic counts of 3.5 and $2.0 \times 10^{1} \mathrm{CFU} / \mathrm{g}$ of coliforms in lamb loin vacuum-packed stored at $4{ }^{\circ} \mathrm{C}$ for 28 days. 
a) Vacuum

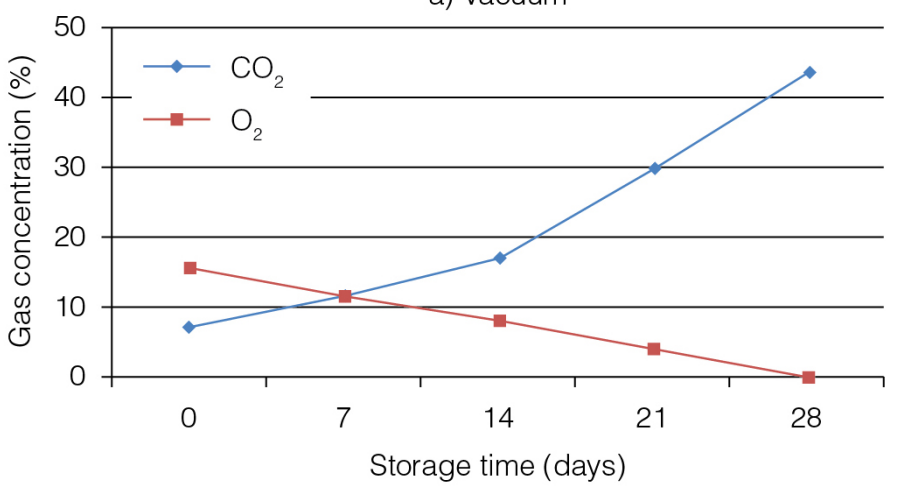

b) Oxygen scavenger

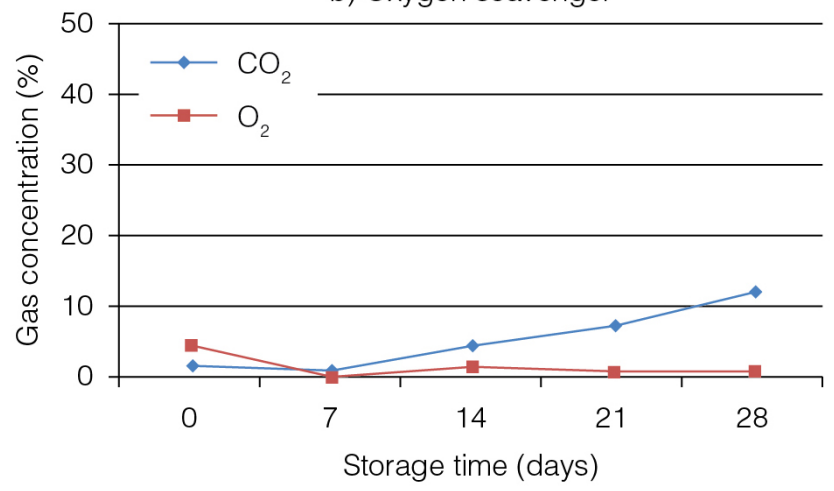

c) Oxygen scavenger/carbon dioxide emitter

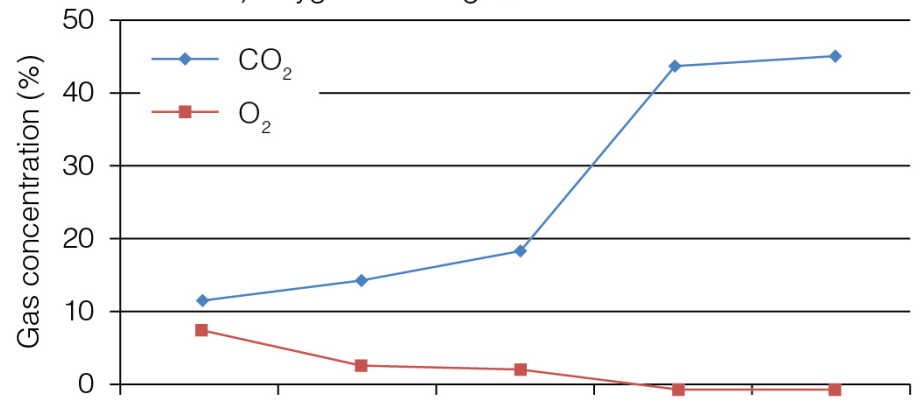

Figure 1. Gas composition inside packages with lamb loins: a) Control (Vacuum packaging), b) Active packaging with $\mathrm{O}_{2}$ scavenger sachets and c) Active packaging with $\mathrm{O}_{2}$ scavenger / $\mathrm{CO}_{2}$ emitter sachets.

Current effect: $F(8,24)=.87818, p=.54832$ Vertical bars denote 0.95 confidence intervals

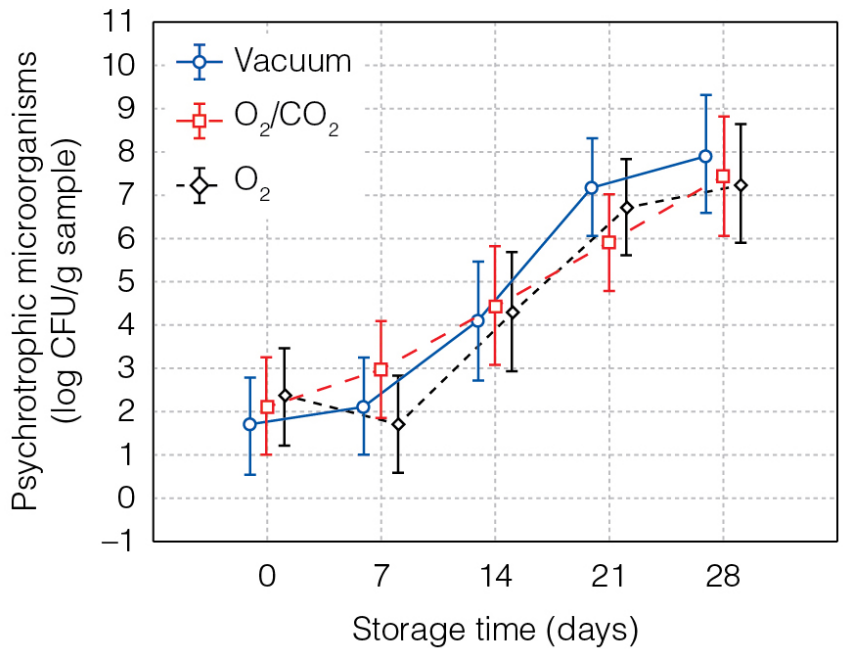

Figure 2. Mean values (log CFU/g sample) of anaerobic psychrotrophic microorganisms counts, by treatment and storage time.

The counts of anaerobic psychrotrophic microorganisms and lactic acid bacteria are shown in Figures 2 and 4 . It was found that samples of the three treatments showed proliferation of these groups of microorganisms during the storage time $(p \leq 0.05)$. However, no differences among treatments $(p>0.05)$
Current effect: $F(8,27)=.91709, p=.51768$ Vertical bars denote 0.95 confidence intervals

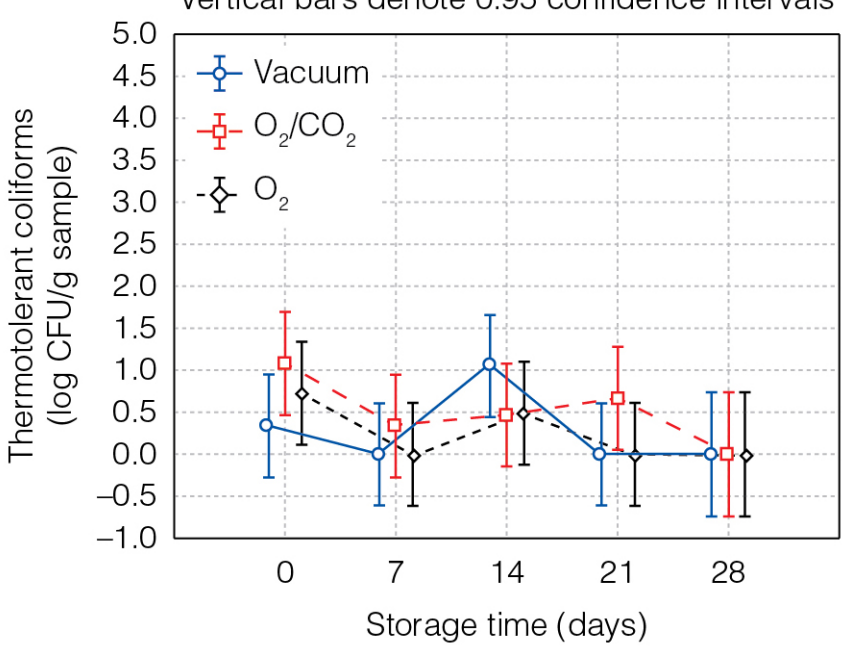

Figure 3. Mean values (log CFU/g sample) of thermotolerant coliforms counts, by treatment and storage time.

were found for both groups of microorganisms, meaning that neither the incorporation of oxygen scavenger sachet nor the incorporation of dual function sachets (oxygen scavenger/carbon dioxide emitter) provided better microbial stability for lamb meat when compared to regular vacuum packaging, during refrigerated 
Current effect: $F(8,26)=.56305, p=.79799$

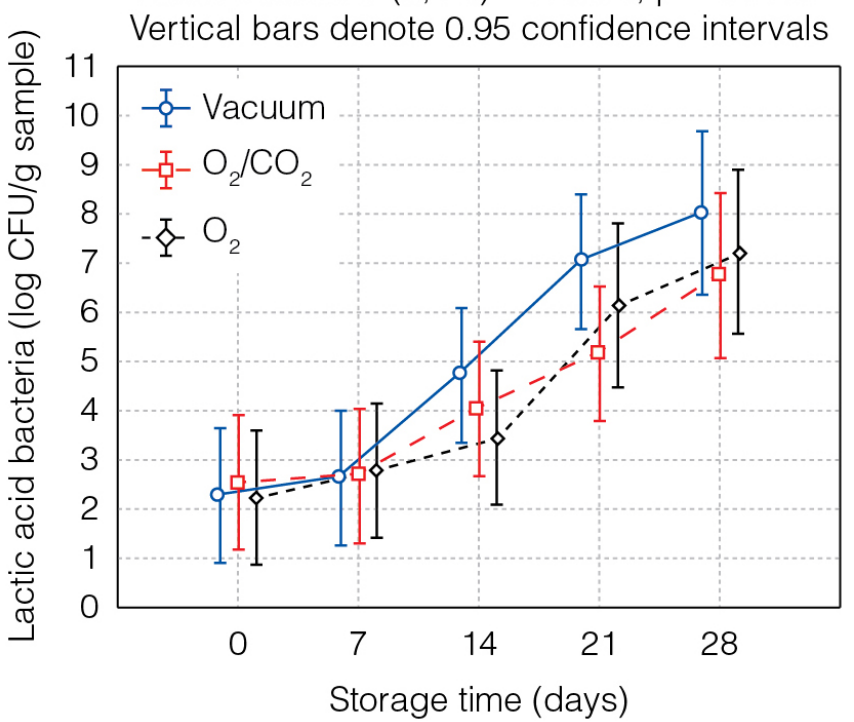

Figure 4. Mean values (log CFU/g sample) of lactic acid bacteria counts, by treatment and storage time.

storage. Probably, the quantity of $\mathrm{CO}_{2}$ generated by the two $\mathrm{O}_{2}$ scavenger/ $/ \mathrm{CO}_{2}$ emitter sachets placed inside the plastic bags, at the evaluated conditions, was not enough to inhibit microorganisms growth. All treatments presented anaerobic psychrotrophic microorganisms and lactic acid bacteria counts near or above $10^{7} \mathrm{CFU} / \mathrm{g}$ at 28 days of storage. According to the International Commission on Microbiological Specifications for Foods (ICMSF, 1986), total counts of spoilage microorganisms should not exceed $10^{7} \mathrm{CFU} / \mathrm{g}$, which would indicate high deterioration. In this sense, samples of all treatments evaluated could be considered spoiled after 28 days of storage at $1{ }^{\circ} \mathrm{C}$. Fernandes et al. (2012) also found counts for anaerobic psychrotrophic microorganisms around $10^{7} \mathrm{CFU} / \mathrm{g}$ sample after 28 days of storage of lamb loin vacuum-packed stored at $4{ }^{\circ} \mathrm{C}$ for 28 days.

\subsection{Physical and chemical stability during refrigerated storage}

As well as for microbiological results showed previously, the incorporation of two the kinds of sachets (oxygen scavenger sachet and oxygen scavenger/carbon dioxide emitter sachet) inside the packages did not represent significant changes on physical and chemical parameters of lamb meat when compared to traditional vacuum packaging.

The analysis of $\mathrm{pH}$ values showed non-significant effect for the treatment, storage time and the interaction between treatment and storage time ( $p>0.05)$, with mean values of 5.5, 5.6 e 5.6 for lamb loins packaged under vacuum (control), with $\mathrm{O}_{2}$ scavenger and with $\mathrm{O}_{2}$ scavenger/ $/ \mathrm{CO}_{2}$ emitter sachets, respectively. These values were within the normal range (5.5 to 5.8 ) for lamb meat reported by Sobrinho et al. (2005). A decrease in $\mathrm{pH}$ values over time could be expected due to the increasing growth of lactic acid bacteria (Figure 2) in all three treatments, but this was not observed. This could be due to the depletion of glycogen reserves in the muscle at the beginning of storage (LAWRIE and LEDWARD, 2006).

For the analysis of objective color in relation to the $L^{*}$ values, there was no significant effect $(p>0.05)$ of treatments, storage time and the interaction treatment $x$ storage time. This means that, besides no difference occurred in meat due to sachets incorporation, the lightness remained stable all over the refrigerated storage period. For the $L^{*}$ value, samples packaged under vacuum (without sachets), with $\mathrm{O}_{2}$ scavenger and with $\mathrm{O}_{2}$ scavenger/ $\mathrm{CO}_{2}$ emitter sachets showed means of $36.2,35.4$ and 35.8 , respectively. These results are similar to those found by Fernandes et al. (2011), for lamb loins packaged in three different modified atmosphere systems and stored under refrigeration $\left(1^{\circ} \mathrm{C}\right)$ during 28 days, where the treatments vacuum, with injection of $75 \% \mathrm{O}_{2}+25 \% \mathrm{CO}_{2}$ and $100 \% \mathrm{CO}_{2}$ showed means of $36.95 \pm 1.05,38.47 \pm 1.05$ and $36.32 \pm 1.05$, respectively. Vergara and Gallego (2001) observed a different behavior in lamb meat stored in two modified atmospheres systems $\left(20 \% \mathrm{CO}_{2}+10 \% \mathrm{O}_{2}+70 \% \mathrm{~N}_{2}\right.$ or $\left.80 \% \mathrm{CO}_{2}+20 \% \mathrm{O}_{2}\right)$, with the $L^{*}$ value of Longissimus dorsi muscles presenting a significant increase over time, ranging from 45.32 to 48.92.

The $a^{*}$ values also did not vary significantly $(p>0.05)$ among treatments or over the storage period and there was no interaction between treatment and storage time. In the same way than lightness $\left(L^{*}\right)$, the redness $\left(a^{*}\right)$ of lamb meat was not affected by sachets incorporation into vacuum packages and remained stable during 28 days of storage at $1{ }^{\circ} \mathrm{C}$, indicating that there was no discoloration in lamb loin surface and pigments were protected from oxidation. The mean values of $a^{*}$ were 7.96 for the vacuum treatment, 7.48 for the $\mathrm{O}_{2}$ scavenger treatment and 7.92 for $\mathrm{O}_{2}$ scavenger $/ \mathrm{CO}_{2}$ emitter treatment. These results are in agreement with those reported by Fernandes et al. (2012), that in vacuum-packed lamb meat the $a^{*}$ value was stable along 28 days of storage at $4{ }^{\circ} \mathrm{C}$, with mean value of 6,96 .

In relation to $b^{*}$ no differences were observed ( $p>0.05)$ among treatments, but there was significant effect $(p \leq 0.05)$ of the storage period, as shown in Figure 5, with an increase in $b^{*}$ values along the storage period. This increase in the yellowness $\left(b^{*}\right)$ could be due to penetration of $\mathrm{O}_{2}$ and consequently higher oxymyoglobin content in the meat samples.

The analysis of water loss from cooking (WLC) showed non-significant effect for the treatment, storage time and the interaction between treatment and storage 
Current effect: $F(8,30)=1.7083, p=.13733$ Vertical bars denote 0.95 confidence intervals

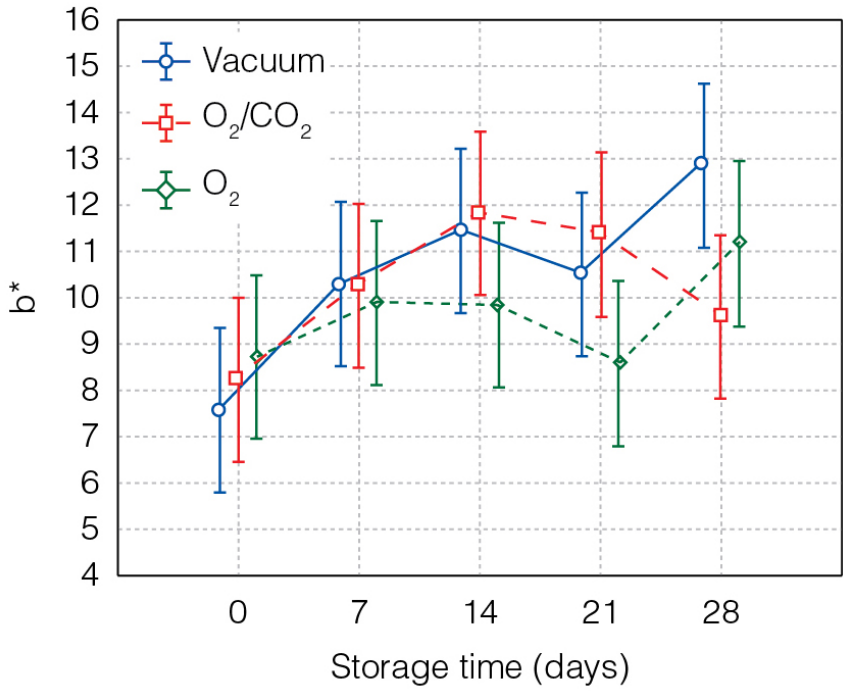

Figure 5. Mean b* values (yellowness) of lamb loins, by treatment and storage time.

time ( $p>0.05$ ). The mean values of WLC were $17.35 \%$ for the vacuum, $16.92 \%$ for the $\mathrm{O}_{2}$ scavenger and $19.22 \%$ for $\mathrm{O}_{2}$ scavenger $/ \mathrm{CO}_{2}$ emitter. These values were lower than the one reported by Caneque et al.(2004), who observed $26.04 \%$ of WLC in lamb Longissimus dorsi after $48 \mathrm{~h}$ of storage at $4{ }^{\circ} \mathrm{C}$.

In relation to shear force, there were no differences ( $p>0.05)$ among treatments. But, as expected due to the meat aging during the refrigerated storage, there was a reduction $(p \leq 0.05)$ in the shear strength values for all treatments over time (Figure 6). Similarly, Bórnez et al. (2010) evaluated lamb loins packaged in two types of modified atmosphere systems $\left(70 \% \mathrm{O}_{2}+30 \% \mathrm{CO}_{2}\right.$ and $69.3 \% \mathrm{~N}_{2}+30 \% \mathrm{CO}_{2}+0.7 \% \mathrm{CO}$ ) during refrigerated storage $\left(2{ }^{\circ} \mathrm{C}\right)$ and found significant decrease in shear force over the storage period.

\section{Conclusions}

In most microbiological, physical and chemical analyzes, there were no differences among lamb meat samples packaged in the different active packaging systems. It could be concluded that, under the tested conditions, neither the incorporation of oxygen scavenger sachet nor the incorporation of dual function sachets (oxygen scavenger/carbon dioxide emitter) were able to extend the shelf life of refrigerated lamb loin when compared to regular vacuum packaging.

\section{Acknowledgements}

The authors would like to thank the São Paulo Research Foundation (Fundação de Amparo à Pesquisa do Estado de São Paulo - FAPESP) for supporting the
Current effect: $F(8,24)=.72592, p=.66749$

Vertical bars denote 0.95 confidence intervals

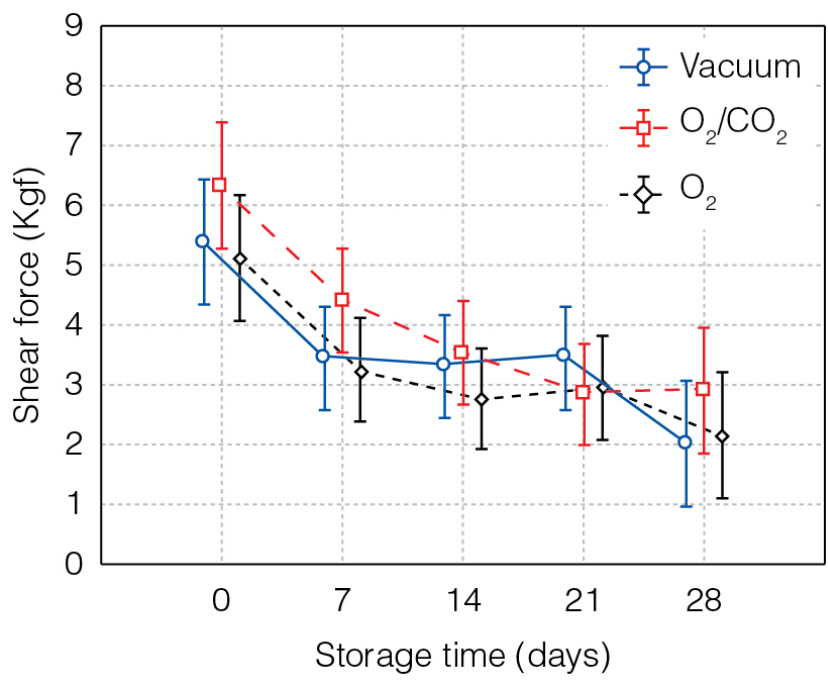

Figure 6. Mean values of shear force (kgf) of lamb loins, by treatment and storage time.

project (Process no. 2009/15555-2) and the scholarship granted to Catharine Vendemiatto Antunes (Process no. 2010/16443-0).

\section{References}

AGÊNCIA NACIONAL DE VIGILÂNCIA SANITÁRIA - ANVISA. Resolução RDC n 216, de 15 de setembro de 2004. Dispõe sobre Regulamento Técnico de Boas Práticas para Serviços de Alimentação. Diário Oficial da República Federativa do Brasil, Brasília, DF, 16 set. 2004. Seção 1. Disponível em: <http://e-legis.bvs.br/leisref/public/show act. php?id=12546>. Acesso em: 31 ago. 2013.

AGÊNCIA NACIONAL DE VIGILÂNCIA SANITÁRIA - ANVISA. Resolução RDC $n^{\circ}$ 12, de 02 de janeiro de 2001. Aprova o Regulamento Técnico sobre Padrões Microbiológicos para Alimentos. Diário Oficial da República Federativa do Brasil, Brasília, DF, 10 jan. 2001. Seção 1, p. 45-47.

AZEREDO, H. M. C.; FARIA, J. A. F.; AZEREDO, A. M. C. Embalagens ativas para alimentos. Food Science and Technology, Campinas, v. 20, n. 3, p. 337-341, 2000. http:// dx.doi.org/10.1590/S0101-20612000000300010

ARVANITOYANNIS, I. S.; STRATAKOS, A. C. Application of modified atmosphere packaging and active/Smart technologies t oread meat and poultry: a review. Food and Bioprocess Technology, New York, v. 5, n. 5, p. 1423-1446, 2012. http:// dx. doi.org/10.1007/s11947-012-0803-z

BLIGH, E. G.; DYER, W. J. A rapid method of total lipid extration and purification. Canadian Journal of Biochemistry and Physiology, Ottawa, v. 37, n. 8, p. 911-917, 1959. http://dx.doi. org/10.1139/059-099 
Active packaged lamb with oxygen scavenger/carbon dioxide emitter sachet: physical-chemical and microbiological stability during refrigerated storage

TRINDADE, M. A. et al.

BÓRNEZ, R.; LINARES, M. B.; VERGARA, H. Effect of different gas stunning methods on Manchega suckling lamb meat packed under different modified atmospheres. Meat Science, Barking, v. 84, n. 4 , p. 727-734, 2010.

BRODY, A. L.; STRUPINSKY, E. R.; KLINE, L. R. Active Packaging for Food Applications. Lancaster: Technomic Pub. Co, 2001. 236 p. http://dx.doi.org/10.1201/9781420031812

CANEQUE, V.; PEREZ, C.; VELASCO, S.; DÍAZ, M.T.; LAZURICA, S.; ÁlVEREZ, I.; RUIZ DE HUIDOBRO, F.; ONEGA, E.; DE LA FUENTE, J. Carcass and meat quality of light lambs using principal component analysis. Meat Science, Barking, v. 67, p. 595-605, 2004.

CARVALHO, S.; BROCHIER, M.A. Composição tecidual e centesimal e teor de colesterol da carne de cordeiros terminados em confinamento com dietas contendo níveis crescentes de resíduo úmido de cervejaria. Ciência Rural, Santa Maria, v. 38, n. 7, 2008.

CHANNON, H. A.; BAUD, S. R.; WALKER, P. J. Modified atmosphere packaging improves retail display life of lamb cuts with variation between loin and knuckle. Australian Journal of Experimental Agriculture, Melbourne, v. 45, n. 5, p. 585-592, 2005. http://dx.doi.org/10.1071/EA03184

CHEN, J. H.; SEOW, R. J.; BANG, W. S.; YUK, H. G. Intervention technologies for ensuring microbiological safety of meat: current and future trends. Comprehensive Reviews in Food Science and Food Safety, Malden, v. 11, n. 2, p. 119-131, 2012. http:// dx.doi.org/10.1111/j.1541-4337.2011.00177.x

COSTA, T. I. R. Qualidade da Paleta Maturada de Cordeiros Alimentado com Diferentes Níveis de Feno Erva-sal. 2011. 42 f. Tese (Mestrado em Zootecnia)-Faculdade de Ciências Agrárias e Veterinárias, Universidade Estadual Paulista, Jaboticabal, 2011.

CRUZ, R. S.; SOARES, N. F.; ANDRADE, N. J. Efficiency of oxygen-absorbing sachets in different relative humidities and temperaturas. Ciência e Agrotecnologia, Lavras, v. 31, n. 6, p. $1800-1804,2007$

CRUZ, R. S.; SOARES, N. F.; GERALDINE, R. M. Avaliação do volume de oxigênio absorvido por sachê absorvedor de oxigênio em diferentes temperaturas e umidades relativas. Ciência e Agrotecnologia, Lavras, v. 32, n. 5, p. 1538-1542, 2008.

FELLOWS, P. J. Tecnologia do Processamento de Alimentos: Principios e Prática. 2. ed. Porto Alegre: Artmed, 2006. 602 p.

FERNANDES, R. P. P.; FREIRE, M. T.; BALIERO, J. C. C.; ROSA, A. F.; CATUNDA, F. A. P.; TRINDADE, M. A. Effect of modified atmosphere packaging systems on lamb meat appearance during refrigerated storage. In: INTERNATIONAL CONGRESS OF MEAT SCIENCE AND TECHNOLOGY, 57., 2011, Ghent. Proceedings... Ghent: Arber, 2011. p. 329.

FERNANDES, R. P. P.; FREIRE, M. T. A.; GUERRA, C. C. G.; BALIEIRO, J. C. C.; TRINDADE, M. A. Estabilidade físico- química, microbiológica e sensorial de carne ovina embalada a vácuo estocada sob refrigeração. Ciência Rural, Santa Maria, v. 42, n. 4, p. 724-729, 2012.

GENIGEORGIS, C. A. Microbial an safety implications of the use of modified atmospheres to extend the storage life of fresh meat and fish. International Journal of Food Microbiology, New York, v. 1, p. 237-251, 1985. http://dx.doi.org/10.1016/01681605(85)90016-9

HALL, P. A.; LEDENBACH, L.; FLOWERS, R. S. Acid-producing microorganisms. In: DOWNES, F. P.; ITO, K. (Ed.). Compendium of Methods for the Microbiological Examination of Foods. 4th ed. Washington: APHA, 2001. p. 201-207. http://dx.doi. org/10.2105/9780875531755ch19

HORWITZ, W.; LATIMER, G. W. (Ed.). Official Methods of Analysis of the Association of Official Analytical Chemists. 18th ed. Gaithersburg, Maryland: AOAC, 2005.

INTERNATIONAL COMMISSION ON MICROBIOLOGICAL SPECIFICATIONS FOR FOODS - ICMSF. Microorganisms in Foods 2: Sampling for Microbiological Analysis: Principles and Specific Applications. 2nd ed. Buffalo: University of Toronto, Press, 1986. p. 127-278.

JAY, J. M.; LOESSNER, M. J.; GOLDEN, D. A. Modern food microbiology. 7th ed. New York: Springer, 2005. 790 p.

JEREMIAH, L. E. Packaging alternatives to deliver fresh meats using short-or long-term distribution. Food Research International, Barking, v. 34, p. 749-772, 2001.

JOHNSTON, R. W.; TOMPKIN, R. B. Meat and poultry products. In: VANDERZANT, C.; SPLITTSTOESSER, D. F. (Eds.). Compendium of Methods for the Microbiological Examination of Foods. Washington: APHA, 1992. p. 821-835.

KAMRUZZAMAN, M.; ELMASRY, G.; SUN, D.; ALLEN, P. Prediction of some quality attributes of lamb meat using nearinfrared hyperspectral imaging and multivariate analysis. Analytica Chimica Acta, Amsterdam, v. 714, p. 57-67, 2012. PMid:22244137. http://dx.doi.org/10.1016/j.aca.2011.11.037

KERRY, J. P.; O'GRADY, M. N.; HOGAN, S. A. Past, current and potential utilization of active and intelligent packaging systems for meat andmuscle-based products: a review. Meat Science, Barking, v. 74, n. 1, p. 113-130, 2006.

KOOHMARAIE, M. Biochemical factors regulating the toughening tenderization processes of meat. Meat Science, Barking, v. 43, n. S1, p. S193-S901, 1996.

LANDIM, A .V.; CASTANHEIRA, M.; FIORAVANTI, M. C. S.; PACHECO, A.; CARDOSO, M. T. M.; LOUVANDINI, H.; McMANUS, C. Physical, chemical and sensorial parameters for lambs of different groups, slaughtered at different weights. Tropical Animal Health and Production, Edinburgh, v. 43, n. 6 , p. 1089-1096, 2011. PMid:21347828. http://dx.doi.org/10.1007/ s11250-011-9806-4 
Active packaged lamb with oxygen scavenger/carbon dioxide emitter sachet: physical-chemical and microbiological stability during refrigerated storage

TRINDADE, M. A. et al.

LAWRIE, R. A.; LEDWARD, D. A. Lawrie's Meat Science. 7th ed. Cambridge: CRC Press LLC, 2006. 442 p. http://dx.doi. org/10.1533/9781845691615

MADRUGA, M. S.; ARAÚJO, W. O.; SOUZA, W. H.; CÉZAR, M. F.; GALVÃO, M. S.; CUNHA, M. G. G. Efeito do genótipo e do sexo sobre a composição química e o perfil de ácidos graxos da carne de cordeiros. Revista Brasileira de Zootecnia, Viçosa, v. 35, p. 1838-1844, 2006.

PINHEIRO, R. S. B.; SOBRINHO, A. G. S.; SOUZA, H. B. A.; YAMAMOTO, S. M. Qualidade de carnes provenientes de cortes da carcaça de cordeiros e de ovinos adultos. Revista Brasileira de Zootecnia, Viçosa, v. 38, n. 9, p. 1790-1796, 2009.

RICCIARDI, A. Embalagens de cárneos. Revista Nacional da Carne, São Paulo, n. 376, p. 39-40, 2008.

SINGH, P.; WANI, A. A.; SAENGERLAUB, S.; LANGOWSKI, H.-C. Understanding critical factors for the quality and shelf-life of
MAP fresh meat. A review. Critical Reviews in Food Science and Nutrition, Boca Raton, v. 51, n. 2, p. 146-177, 2011. PMid:21328110. http://dx.doi.org/10.1080/10408390903531384 SOBRINHO, A. G. S.; PURCHAS, R. W.; KADIM, I. T.; YAMAMOTO, S. M. Meat quality in lambs of different genotypes and ages at slaughter. Revista Brasileira de Zootecnia, Viçosa, v. 34, n. 3, p. 1070-1078, 2005.

VERGARA, A.; GALLEGO, L. Effect of gas composition in atmosphere packaging on the meat quality of Spanish Manchega lamb. Journal of the Science of Food and Agriculture, London, v. 81, n. 14, p. 1353-1357, 2001. http://dx.doi.org/10.1002/ jsfa.953

VYNCKE, B. W. Direct determination of the thiobarbituric acid value in trichloracetic acid extracts of fish as a measure of oxidative rancidity. Fette Seifen Anstrichmittel, Leinfelden, v. 72, n. 12, p. 1084-1087, 1970. 